\title{
The Korean Accountancy Market and Global Competition
}

\author{
NU Ri JUNG; AND WONSEOK WOO*
}

\begin{abstract}
Among the professions, accountancy services play an especially critical tole in the matket econony today; thus, there have been many Work: 'Trade Organization (WTO) attempes. beyond the Gencral Astement on Trate in Services (GA'TS), to liberalizc the marker for accountancy services. in response to this international demand. the Kortan government announced the liberalization of its accounting market from 2007 and its full opening by $20 \mathrm{l}$. This paper begins with an overview of the Koncan accountancy market, including a $S W O Y$ analysis focused on the post-fictacial crisis era. Nexe, it shows how the WTO pacts - especially the GATS and the Disciplines on Domestic Regliation in. the Accountancy Sector (Disciplines) - and 'Revised Conditional Ofter on the Schedule of Specific Commitmonts' for $\mathrm{W} \mathrm{TO}$ services negotiations submitted by Korea on May 31 , 2005 are uscot io cieminate chese domestic regulatory barsicrs to international trace in accountancy services. Finally, the paper anticipates both the positive and the negative implications of accontancy makct liberaizacion in Korea following from the removal of exiscing obstackes to cross-border tradc. As the first sector to be disciplinat under the GATS, the liberalized accolintancy sector is likely ro becone the mocel for other professional services such as law, health, engineering and architecture. Hence this study can have significant implications that extenci boyond the field of accounting.
\end{abstract}

Konards: Global accountancy services, WTO negotiations, Korean accouncancy marker, Globalization, Reliability of financial accounring informaiton, Corporate governance

Firsi Author: Nu Ri Jung. Candictate loz LL.M. (Mester of Laws:. Indiata Craversicy School of

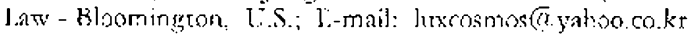

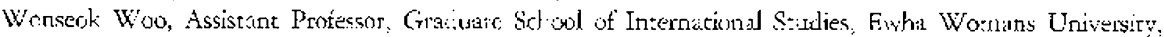

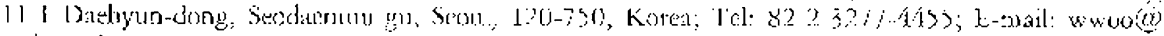
ewhackes 


\section{MNTRODUCTION}

A mong the professions, accountancy services play an especially critical role A in the market econony today; thus, there have been many WTO atemupts, heyond the GATS, to libetalize the masket for accountancy services.1 For exannle, the Disciplines on Domestic Regulation in the Acountancy Sector represent the WTO's first attempt to excrcisc its authority to impose disciplines on non-discriminatory domestic regulation unrier the GATS Asticle VI: 4.2

In response to the international demand, the Ministry of Tinance and Foonnmy (MOFE) of Korea announced on December 7, 2005 that the Korean grovernment will open its accountancy and other professional-services sector nacketsets ${ }^{3}$ to foreign companies in $2007, \%$ in order to increase its goals of attracting more foreign inyestors atsd making Korea the financial hub of Northeast Asia. Accordingly, it will overhaul finaricial regulations and related laws. Thas step is in line with

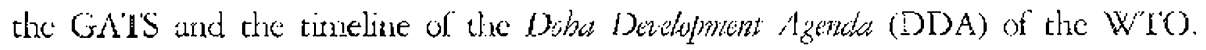
The government is stepping forwated this year in planning to open up the market fully by 2011.5

The purpose of this paper is to critically cxamine the liberalization of the Korcan accountancy market. As the first sector to be disciplined under the GATS, the (liberalized) accounnancy sector is likely to become the model for other professional services such as law, health, crigincering and architecture. ${ }^{6}$ The globalization of accountancy services nighit eventually lead to the restnucturing not only of the market for accountancy services but also of that for other professional services as well. $\bar{i}$ Hence, this study can have implications that extend beyond the field of accounting.

The paper first conducts a rudimentary SWOT analysis of the accountancy market in Korea, and documenes the currene liberalization of the Korcan accountancy market. Next, it anticipares both the positive and necrative implications of accountancy matker liberalization in Korea. Finaliy, it suggests policy recommendations.

\section{OVERVIEW OF THE KOREAN ACCOUNRANCY MARKET}

As Korea is the third largest cconomy in $\Lambda$ sia and $11^{\text {Lh }}$ largest in the workd, the size of the Korcan accountancy market is also significantly large. Korca also boasts many talcnted professionals in the accountancy sector. According to the Yinancial Supervisory Service (ESS), the nation's tocal number of cerrificed public: accountants (CPAs), including 4,931 CPAs regisiered wirh 79 accounting firms, increased by 18.7 percent, from 7,148 in March $200 /$ to 8,185 in March 2005. The number of CPAs working at those 79 firms surged by 27.2 percent, from 3,880 to 4,934, over the same period. As of March 31, 2006, there 
arc 9,285 C.PAs in rotal, accurding to the Korcan Institute of Certified Public Accountants (KICPA). As the size of the Korean professional-services market grows with time and liberalization, 9 it can be antiripated that the size of the Koytean accoumancy market will increase as well.

inder a gencral. consensus that a deficiency in accounting standards, a lack of enforcement of the proper stundards that did exist, and unsuccessful monitoring were three of the major causes of the financial crisis in Korea, the Korean govemment since 1997 has taken significant measures to improve accounting and auditing standards and practices and to streingthen the underlying institutions responsible for setring standards and cnsuring compliance. As a result, there have been sweeping reforms in the overall accountancy system: (1) almost all of the financial accounting standasds have been substantially rewriten to conform with the Inicrational Arouming Standards (IAS); (2) an independent privare standands-serting orranization, the Korea Accounting Insticute (KAl)/the Korca Accounting Standards Board (KASB), which is latgely consistent with the International Tinancial Reporting Standards (IFRS), was established; (3) as the auditing profission was on the verge of radical changes, and as independent directors were required to take a leading role in corponate governance, an audit committec was adopred to provide a formal vehicle for performing the monitoring function, 10 and the Korean Auditing Shadawh (KAS), a translation of the ISA, was legislated by the KICPA.11. Furthermore, the Korcan government, in Decentler

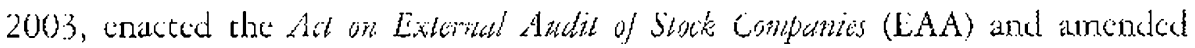

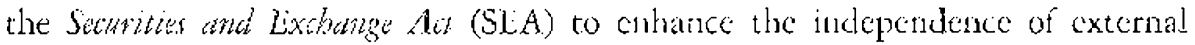
auclitots. "2 These refortas ase expected to contribure: to a bighly developed Korean accounting sector.

One of the most critical wcaknesses in the Korean accountancy masket is reflected by the outbreak of a string of accouning fraud scandals. For example, major conglomerates such as SK and Doosan were prosccured for dressing up their accounting books to inflate profits. Exen though the Korean government has fostered a tougher regulatory environment, accounting frauds are still being committed. The occumence of such scandals calls into question the credibility and independence of the accounting profession. Strongthening sanctiuns or devising stricter regulations is ineffectual withour the participation of both parties, the ascounrancy scrose and the government. In the meantime, the existence of too many strict regulations is anouher weakness of the Korcan accountancy market.

Accounting firms or joint audit teams in Korea cannot afford to hise aj] of the growing rumber of C.PAs coming out of the unversitise, duc to the low audit fees in Korea compared with other councries. The govenment has increased the number of candidates passing the CPA examination each year from about 500 in the past to at least 1,000 since 2001. Many of them have not beco able to find positions at accounting firms or join audit teams. In order to ease this problem, the Certified Public Accountant Law, amended in December 2003, 
shortened the period of practical experience that is royuired before an individual can register as a CPA, from 2 yoars to 1 year. 13 However, the problem has not been mucl! allevizited.

Inlike hig accountiog forms that already have an international affiliation with foreign accounting firms, such as Samil PwC, Deloite Anjin 1.LC, and Samjong KPMG, ${ }^{1-1}$ small- and medium-sized accounting practices are not yer filly prepared for the liberalization of the accountancy matket. When national regulations that protect the donestic accountancy market from globaization dismantled, those small- and medium-sized accounting practices will become vuluerable to consolidation by large piofessional-service conglomerates. Even for the latge accounting firms, it will not be easy to survive amid toligh international compctition.

Although Korean accountancy market has its wcaknesses, there are certain opportunities especially for forcign acomutancy services firms. Northcast Asia today is rapidly becoming the mose comomically potent region in the world, contributing about 22 percent of world output. The region will make up alout 30 percent of global GDP by 2020.15 This regroral advantage works as an incentive for Korea to expand its market and induce more foreign direct investment (IDI). Recently the Korean government estabished the goal of becoming the financial hub of Northeast Asia, and to attract more foreigis investors, it commenced negotiarions on a free trade agreement ( $F i A$ ) with the Cnited Stares. As a first major step, the government aims to lay the essential foundarion, that is, to upgrade the rcyulatory system, and to liberalize the professional-setvices market by 2007. 'linis will be a challonge, but can also be an opportunity for Korea and its accoumancy tarket.

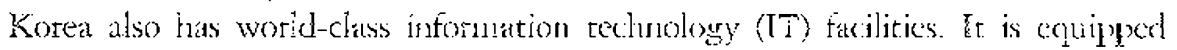
with a hitech infrastructure and boasts high-quality IT matipower. Korean financial institutions are the mose efficienc in the word in the electronic transfer of finds and payment settlement. ${ }^{16}$ This technological facto is important, because. IT is very directly relevaint to accountancy services todidy, given the increasing traffic in electronic commerce, the developmen: of the accounting information systam (Als) and the computer-assisted audit technique (CAA'), and othes such icuprovemuts.

As mentioned previously, market liberalization can be botl an opportunity for and a threat to the Korcan accountancy market. The Korcan accountancy market is now facing stiff competition from large Western accouncing firms. One of the prospective negative effects of iilveralization is the loss of the market share of domestic accounting firms. For somal accounting fums, the competition will be more aggressive even at the level of penetrating the market. The scond threat is the Joss of CFA jobs due to the introduction of the paperless audit and gencrally increased dependence on IT.-7 IT development will affect the employment prospects of $\mathrm{CH} A \mathrm{~s}$ as well as those of cmployecs in other industries. 


\section{INCOMING LIBHRAIYLATON OF IHE KOKEAN ACCOKJTEANCY MARKET}

Regarding accountancy services as well as other professional services, the obstacles to international trade are predominatcly regulatory barrices, such as diverse national and sub-national licensing and qualification requirements, regulations limiring the scope of practice and the forms of business organization, and non-harmonized technical, educational and ethical standards. ${ }^{18}$ As a remedy to these ills, the liberalization of the accountancy market will mean that non-national accountants would be able to offer accountancy services under the sane concitions as nationals, and thus forcign accounting firms might be able co establish oflices without requiring locally approved professional accountants. ${ }^{19}$

With respect to accountancy, the GAIS defines "trade in services" broadly to encompass accounting and audit services dediverced across borders through clectronic rechnologies, dircet forcign investment in accounting and auditing firms, and the movement of professional workers across borders in order to practice as accountants and auditors. The GATS not only covers all cypes of services but also applics to all possible modes of delivering services. Those modes are: (1) cross-border delivery, (2) consumpcion abroad, (3) commercial presence, and (4) movement of natural persons. Nations can liberalize trade in accounting and audiaing in any of the four modes of scrvice by guaranteeing market access 20 and national treatnent ${ }^{21}$ to all WO 10 Members on a most-favored-nation basis. 22

Market-acess and nacional-trcatment cominitments are prescribed nationally through the "Schedules of Specific Commitments (Schedulcs)," which are annexed ro the GATS. The Schedules also specify any limitarions on marketaccess or national-ereatment commitmenes that a country cas apply. Acoording to the "revised offer on the Schedule of Specilic Commitments of Korea for the WTO Service Negotiations" on May 3i, 2005,23 Korea is open in Modes 1 and 2 except for auditing services that are unbound. Iimitations apply to commercial presence, and special temporary cntry is allowed under Mode 4 for forcign accountancy, training and transfer of technology.

In other words, the revised schedule accords market access and national treatment to forcign firms wishing to provide accounting and bookkeepirg services through cross-border supply and consumption abroad, but loave unbound restrictions on the provision of andicing services through those modes. Korea permits the supply of accounting, bookkerping, and auditing services through commercial presences provided that they are established as solc proprictorships, auditing task forces, joitt accounting offices, or incorporaced partnerships run by cerrificd public accountants (CPAs) licensed under the Certificd Public Accounting Iaw. In order to receive such a license, forcign accountants must have two years of experience in Korea after passing the CPA examination. Korca's limitations on the presence of forcign personnel are left untouched, although cross-industry 
commitments provide for the encry and temporary stay of exceutives, senior managers, and specialists for periods of up to thres years.

Athough foreign accountants and firms canno provide external audit services directly or externally, in face such accomonts and firms are already active in Korea in the form of international affination with Koran accounting firms or. offices. The actual momentun was the financial crisis of 1997. During the post-crisis restructuring stage of the Korean corporate and financial communities, the International Monetary Fund (IMF) recommended to the Financial Supervisory Commission (FSC) of Korea that large Korean financial institutions with assers of over 800 bilition won be audited by accounting firns that had entered into audit-quality-control contracts with recogrnized istremational accounting firms. As the recommendation followed the overall loss of incernational confidence in the reliability of the financial statements of Korean private enterprises and financial institutions, almost all of the large fuxancial institutions in Korca have

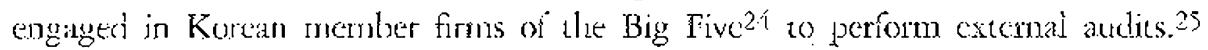

Additionally, the Scheculce permits a Koran accounting firm or office to gain membership in intcrnational accounting organizations heving world wide business nerworks by paying an annual membership tec. Through this membership contract, consultancy for foreign accounting standards and audicing, trainings of CPAs, transfer of auditing technology and exchange of information can be supplied to a Korean accounting firm or office. Also, becalse the Schedule approves accounting corporations - limited-liabilicy companies (1:Cs) - of CPAs licensed under the Certified Public Accountant Law, foreign accounting firms are participating in the Korcan accountatcy tnarket by cstablishing Lles with Korcan accounting firms.

As of August 31, 2005, according to the FSS, three accouncing furns - Samid Pricenaterhouse(oopers (Pw(), Deloite Anjin and Frnst \& Young Koreadominate Korea's domestic auditing and consulting services market. "Ihe FSS stared that the number of CPAs working at the infee maior firms currently stands at 2,742, about 56 percent of the 4,934 CPAs regstcred with 79 accounting firms. About 30 percent of the 4,934 CPAs - 1,41: CPAs - at the 79 accouncing firms nationwide worked for Samil $\mathrm{j}_{\mathrm{W}} \mathrm{C}$ in March, 2005. Delorte Anjin and Ernst \& Young Korea employ 666 and 662 CPAs, respectively. As corporate clients' reliance on larger accouncing firms has become a global trend, thusc large accounting firms affiliated with global players capture a greater portion of market share by offering high-quality auditing and consulting services. For example, Samil PwC, posted 296 billion won in sales during the 2005 fiscal year, from A pril 200\% to Marcl 2005 , accounting for 33 percent of the rotal sales of the 79 firms. 26

According to the ncws released on April $\%, 2006$, the MOFE will suggest the amendment of the Cerrified. Public Accountant Law from January 2007 , in order to allow foreign accounting firres to open branch offices in Korea 
and to permit Korcan accounting forms to umploy foreign accountants. This would be a significant change, if realized, because now, foreign accountauts and accoututing firms can wotk in Korea only under the satisfacrion of the restricted conditions. ${ }^{2}$ ? The amendment also includes direct consulting of forcisut accounting firms to Korean corpuratc dients. Furthermore, the Korcan govemment is now consiciering allowing FIJ of foreign accounting fitms that goes beyond simple international affiliation with a Korcan accounting firm. 29 In the end, the Korean accountancy market will be fully liberalized - even allowing for Mode 4 of the GA'l'S - by 2011.

Alhough the accountancy market secms to have adapted to global competition somewhat since 1997 , accelcrating liberalization would be prukdent. Once a country undertakes commirments in the accounting sector, they become bitading and cannot be altered easily. More precisely, WTO Members may schedule limitarions on their markct-access and national treatment commicments at the time those commitments ate undertaken in order to preserve their right to maineain or adope non-compatible domescic regulations. Scheduleci litmitations can be removed in the course of funde negotiation to allow progressively higher levels of liberalization, but schedules may not be altered to modify or withdraw market access and aational treatmont commitments with impunity. $2 y$

Therefore, the Korean govemment should be careful when revising the Schedule, and should be even more cautious in the case of accountancy services, because accountancy services deal in confidential clicne information. Moteover, considering that sales per Korean employee is only 36 percent of sales per Ainerican employec in accounting scrvices, 30 radical libetalization might produce unexpected results.

\section{MMPLICATIONS OF IIBERAIIZATION}

The effects of liberalization can be evaluated either positively or negatively, depending on the domestic and international situations.

\section{Prospective Positive Effects}

Further liberalization of the accouncancy matker has the porenrial to restructure ic by facilitating direct foreign investment, transfer of advanced skills and professional labor, cross-border delivery of services, connectivity to global networks, and mergers of local practices, all in the effort to compete with foreign joint-venture firms. Harmonized licensing and qualification standards with the GATS commitments to movement of natura persons (Mode 1) in service markets - Korea has not approved this provision of the commitments yet - will allow licensed accounants to move freely from one country to another. Accordingly, it becomes possible for accounting frrms not only to move senior personnel around the 
world more casily but also to bring accountanis from lower-wage labor markers to porform temporaty work assignments. ${ }^{31}$ The GA1S commirnents to coss-bor. der trade (Mode 1), in combination with muttel recognition agresments, will also make it possible to "offshore" professional work - to electronically transnit work to arcountanes located in lower-wage markets. 32

\section{(1) Enhancement of the Refiability of Financial Accounting Information}

As previously mentioncd, the 1997 frrancial crisis in Korea was partially duc ta the overall loss of international conficence in the reliability of the firancial accounting information of Korran privalce enterptises and financial institutions. Since then, Korea has struggled to recover internarional confidence by pursuing fundamental reforms in the arcountancy secror.

The reliability of financial accounting information cannot be achieved casily, because it results from a combination of high-quality accounting standards, tigotous interpretation and faithrid application, and independent and professionaliy reliable external audits. 33 As the liberalization of the accountancy market can lead to the transfer of advanced skills necessary for improving auditing independence, audit quality, and reviews of audir engagement, Rorea can leam methods of enhancing the reliability of inancial accounting information more eflectively and effeciently though liberalization. The enhancement of the reliability of financial accounciag information promises more rlan what it minimally implics; that is, it promises the reciuforcement of international competitive power. The level of the reliability of financial accounting information detcrmincs the level of risk on an investmer.t. Therefore, the enhancement of the rciability of financial accounting information will spur foreign investment into the local Korean market and, finally, smouth the transition of Korean accounting firms into inceraational markets.

\section{(2) Promotion of Horcign fnvestment}

One of main rationales for opening up the accountancy market is to attract more forcign investment. 3 This is why countries open their markets even at the risk of many negative effects. Because deregulation of markets makes it easier for toreign investors to access those markets, to invest, and to make profits, market liberalization typically induces foreign investment. As the liberalization of the accountancy market, as mentioned previously, will erdhance the reliability of financial accounting information, the effect on the growth of foreign investanente will be greater than that produced by the liberalization of other sectors.

\section{(3) Export of Korean Accountancy Services}

The liberalization of the accountancy markct means that the Korean accountancy 
marker has to compete with the global competition, which challenges will force domestic accounting firms to improve their operations. Through this process, the Korean accountancy market, in the end, will be restructured to meet the requirements of global competition and export.

It is rrue that the Korean accounting sector is relatively less devcloped than those of Western countries. Huwever, it is also true that it is relatively highly developed comparcd with chose of Southeast Asia or the Middle East or Africa. Korea has an absolute advantage over those underdeveloped countrics in accountancy services as in profissional sarvices generally. Particularly in the GAIS comtajuents to cross-border iracte (Mode 1), Kotea has the crucial comparative advantage of world-class IT farilities. An integrated glolal market for accountancy services means removal of national. borders not only for forcign accounting firms but also for Korcan firms. Korca can confrdently take this risk as a chance to export irs accountancy scrviccs to areas of the world where Korea has a comparative advantage and the opposcunity, thereby, to earn significant profits.

\section{Prospective Negative Effects}

Efforts to eliminate regulatory barriers to trade in accounting and auditing services coukd have damaging repercussions for the public interest and consuner protections, the relations of exchange between developed and developing countries, and the ability of governments to regulate the conduce of business. The domestic regulations that are viewed as bartiers to trade in accounting and auditing services are: (1) citizconshy or residency requirements for protessional licensure, (2) restrictions on ownership and forms of business organization (c.g. laws that himit ownership of accounciog firms to licensed accountants, or probibit corporate forms of accounting practice), (3) Jocal hiring requircments or local cquity tcquircments, (4) immigration laws restricting the mobility of personnel, (5) the scope of practice limitations, and (6) iational standards that diverge from international standards. 35

\section{(1) Loss of Accounancy Martiet Share}

Flimination of these regularory crade barrices would bonefit major transatantic accounting firms that export services, and would facilitate their ability to cxpand and consolidate their glohal operations throngh Fin and acquisition of local ijrms. However, the benefits would hardly be shared ecjually among developing countrics, or across social and occupational groups within exporting countries. In other words, as these national regulations are dismancled, small - and me - dium-sized accounting practices become vulnerable to consoliclation by large professional-services congloneraces, 36 Meanwhile, countries such as the Linited States, the EL, Camada and Australia, having highly developed accounting sectors 
that are capable of expanding globally and cxporting accounting and audicing services, receive a disproporionate share of the benefints from the deregulation of crade in accountancy services. 3 ?

Korea, like other devcloping countrics, cmploys measures such as local hirings requirirements, local cquity requirements, tases on repatriarion of profits, and citizenship or residency requircments in order to prevent indigenous accounting industrics from being swallowed up by international fictns. Local hiring requirements foster the development of local professional expertise and the requisite professional infrastructure for emerging economies. Sinzilariy, equity requircments that domestic accountants hold some share of the ownership of accounting firms are a viable strategy for economic developnent. 38

Without those means to protect and foster domestic accounting sectors, devcloping counrries would find dheir accounting sectors doninated by lasge Western accounting firms that would likely be mowe concerned wibh scrvicing their andtinational clients than with dcveloping local comomics. ${ }^{35}$ The elimination of such protectionist masurcs could ultiniately limit development scmategies and perpetuate incouitable relations of exchange between developing and developed countries 40

\section{(2) Infringement of Public Inzerest and Consumer Protections}

Citizenslip or residency requirements for accounting licensure run counter to accountancy market liberalization because they discriminate against forcign accountants. Howeves, such requifenents procect consumers from malpractice by making disciplinary control more pracricable and by facilisang the ability of injured parties to stue for negligence. 11 Jience, resickency reguirenents can be a legitimate means of protecting consumers aganst non-performance, malpractice, incompetence and breach of confidence. Restrictions on forms of owncrship, forms of business orgarization, and scope of practice, likewise, serve prudential purposes. î

In sum, these types of donesric regulations not only constirute barriers to market access by foreign accounting firms that operate as multi-practice, limited-liability corporations, but also effectively regulate anditing practices and stem abuses in financial reporting. "ihcreforc, the climination of regulatory obstacles to rrade in accounting and auditing services has detegujatury effects that coukd impair audit quality and the integrity of financial reporting in both developing and developed nations. 13

\section{(3) Confijets with Domestic Governance}

Mary of the perceived regulatory barriers to trade in accounting and auditing services touch upon delicate domestic policy issues. The mobility of professional workers involves sensitive inmigration issues that have implications for labor 
markets in borh developed and developing wations, and the decision to aclopt inccmational accounting and andiring standards has implications for the integrity of tinancial reporting. 44

if WTO Niembers agree to undertake market access or national treatment commitments in the acrountancy sector, they may not maintain or adopt domestic regulations that at: incompatible with those commitments. Restrictive immigration laws are incompatible with maket-access commitments regarding the movement of natural persons (Node 4), while residency and citizenship requitements conflict with national treaunent commitments that guarantee that foreign suppliers are trated "no less favorably" than dornestic supplicrs. Local equity requirements and prohibitions of corporate forns of ownership also violate lhe CATS marker-access commitments, which stipulate that tations may not limit "the participation of furcign capical in terms of maximum percentage limits on foreign sharcholding" or maintain "measures which rescrice or require specific rypes of legal entiry or joint venture through which a service supplicr may supply a service." 45

The GATS not only limits discriminatory laws such as citizenship and residency requirements but also affects non-discriminatory domestic regulations. Inder the GATS market access provisions, nondiscriminatory domestic laws can be deened discriminatory if they inadvertently preclude foreign firms from competing in domestic markers. Furthomore, the GATS controls on donestic regulation can apply to non-discriminatory domestic regulations. 66

limitations on practice scope and restrictions on corporate forme of ownership are potcontially illegat according to GATS - even when applied equally to forcign and domestic firms -- because: the efiect of such linws is to exclude foreign accounting firms that operate as multi-practice, limited liability corporations. Some analysts have even interpreted bans on advertising as discriminatory on the grounds that they disadvantage foreign firms that are new to the market and reliant on advertisement to establish their business presence. B? Because the GATS can infringe on an array of non-discriminarory domestic regulations, ic docs more than merely creatc a level playing field for foreign competitors in domestic markets. It potentially limiss the ability of governuments to effectively govern the practice of accouncing within their own borders. is

\section{POI.HCX RECONMMENDATIONS}

Some people portray globalization as natural and inevitable, as an impersona! and immutable force that workers and companics must adapt to and accommodate, and that nations are powerless to control or subordinate it to goals such as a sustainathe economic development or greater social cquity. Others, especially analysts witing in recently published papers, argue chat global markets are 
politically constructed institutions that are shaped by non-market actors - inclued. ing noultinational corporations and industry trade lobbies - by moans of international trade agrecments, (1)

Considering the formation process of intcrnational agtetments, the latter seerns more reasonable. I Iowever, for Korea, which is still in the pasition of a standard-taker, not a standard-maker, it is also true that globalization is the inevitable trend. Hence, for Korea, the internationai convergence of accounting standards $s^{50}$ and the liberalizarion of the accountancy market are irreversible trends under economic globalization. Given these circumstances, what is left for Korea is to take this risk and make the most of its oppotturitics. The following are recommendations for how Korea - government, induscry, and eutities - can cope with the situation.

1. Recommendations for the Public Sector: Government and the Accountancy Industry as a Wholc

Accountancy services have bect a sector in which fore:gn professionals have not been allowed to freely operate in Korea. Thus, the announcement of the Korcan government that it will open up its accountancy market to foreign companies in 2007 and cven allow all modes of the GATS by 2011 has significant implications for the Korean economy. Therefore, first, the Korean government should try to minimize the prospective ncgative effects of accountancy market libcralization on the Korean domestic market by taking strategrically tailored approaches to the negotiations. Second, hecause internal negutiations ate as inportant as excernal unes in facilitating globalization and market liberalization, internal negotiations shoukd entail the promorion of the advantages of an open market, the establishment of a two-way communication channel between the government and yarious interest groups, and the conrination of differing views on liberalization.

Third, in order to prepare for extcrnal libemalization in accounting services, it is imperative to establish a system for recognizing the competence of foreign accounting professionas. That $i$, it is necessary to provide an objective cvaluation mechanism for the education and training of foreign license holders. Fourth, the government reeds to upgrade the domestic licensing system by introducing continuing education for license holders.

Hifth, Korea should promote structural retorns that increase market liberalization. Adopting the IHRS can advance a country's cconomic growth and provide a platform fo: companics to provide more trausparent financial reporting. Thus, the Korea Accounting Srandards Board (KASBs) needs to make additional efforts to renove discrcpancies between local accounting standards and the IrRS.51 After all, the KFAS has to be the one conforming to global standards, not the other way around. In orher words, it is important to keep the KFAS consistent 
and in hamony with the best global pracieces and standards.

Sixth, the Korcan. Institute of Cerrified Public Accountants (KICPA) needs to issue additional best-practices guidance to help implement auditing standards to restore public confidence, since the outbreak of a string of accounting fraud scandals - the dressing up of accounting books ro inflate profits at such major conglomerates as $S K$ and Doosan - calls into question the credibility and indepondence of the accounting scrvice. The audit commictec needs to be mandated for smaller listed companies, and its rolc noeds to be strengthence. The statutory regulator should consider strengthening sanctions against violators of standards and rules, and should put in place improved axangements for efficient and effective oversight of auditors of public companies and for moniroring of accouting firms. 3 ?

Seventh, what is more important cven than the rigorous application of tougher standards for accounting transparency is the willingness of each player in the accountancy market ro pursue best practices. The occurrence of those scandals promped the Korcan government to devise a tougher regulatory envirnnment that was modeled on the Sarbanes-Oxley Act of the Inired States (sec Table 1 for the comparison). 5 However, as the fact that other accounting scandals occurred even after those regulations were institured indicates, strengthening sancrions or toughening regulations is futile without the willing compliance of each player.

THULE 1. COMPAZISON BELWLEN SABBANIS-OXLEY ACT OI 2002 AND RI:CENT LEGISLATLON IN KOREA

\begin{tabular}{|c|c|}
\hline Sarbanes-Oxley Act of 2002 & Recent Iegislation in Kirea \\
\hline $\begin{array}{l}\text { Ser } 10:-107 \text { Eitabishorent } \\
\text { of the Public Company } \\
\text { Acconning Oversight Boutd }\end{array}$ & 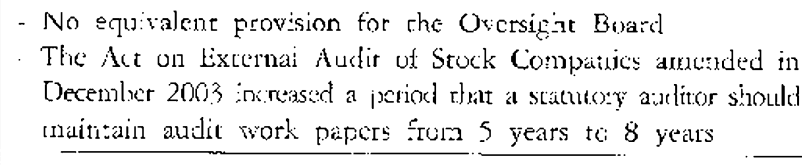 \\
\hline 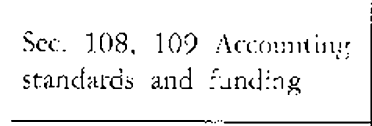 & 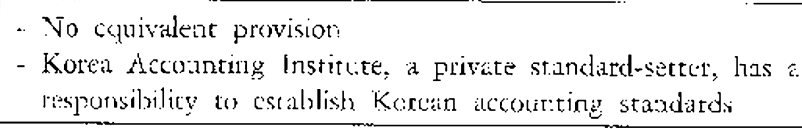 \\
\hline $\begin{array}{l}\text { Scc. } 201 \text { Prohibit } \\
\text { services }\end{array}$ & 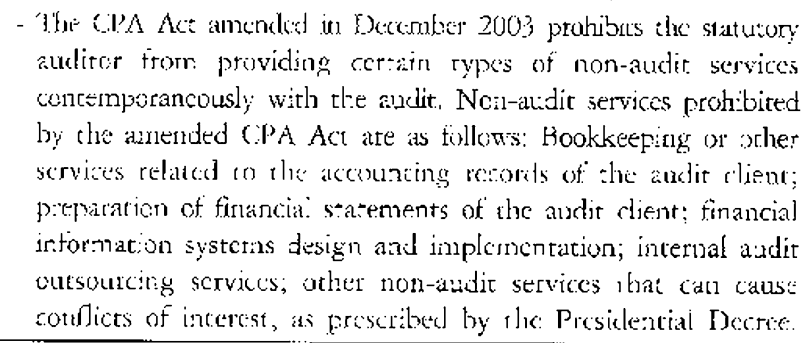 \\
\hline $\begin{array}{l}\text { Suc. } 203 \Lambda_{\text {urilit part }} \\
\text { rotation }\end{array}$ & 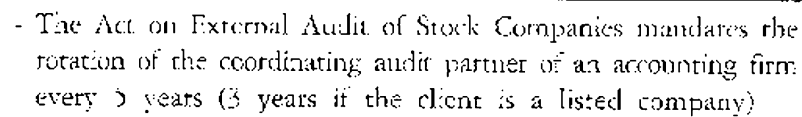 \\
\hline
\end{tabular}




\begin{tabular}{|c|c|}
\hline Sarbanes-Oxley Act of 2002 & Recent Legislation in Korea \\
\hline Scc 206 conflicts of interest & 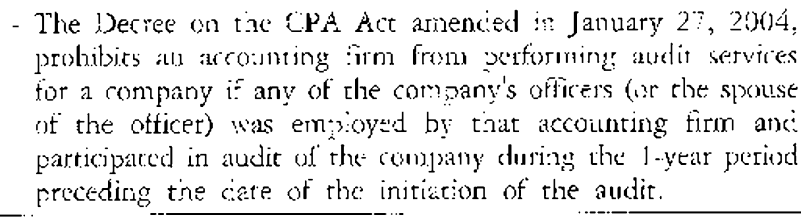 \\
\hline $\begin{array}{l}\text { Sec. } 207 \text { Study of } \\
\text { mandatory rotation of } \\
\text { reyistited public } \\
\text { accomting firms }\end{array}$ & 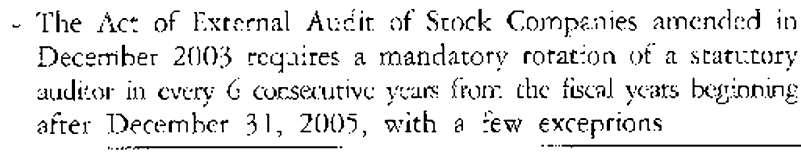 \\
\hline $\begin{array}{l}\text { Sec, } 302 \text { Corporate } \\
\text { esponsibilicy of financial } \\
\text { icports }\end{array}$ & 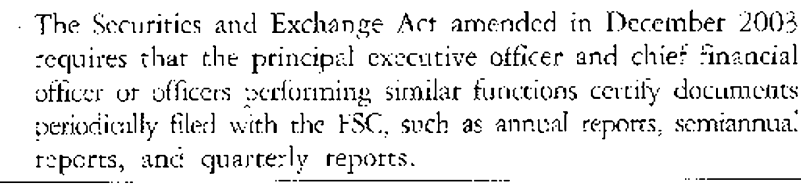 \\
\hline $\begin{array}{l}\text { Sec. } 402 \text { Enhanced conflict } \\
\text { of interest provisious }\end{array}$ & 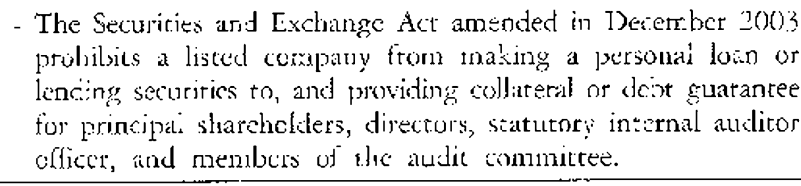 \\
\hline
\end{tabular}

Sec. 403 Disclosurcs of transartions involving managemeas and priscipal stockhoiders

Sec. 仿禾 Mankigemcint asscssment of irutetual cuntrols

Sec. $40-7$ Disclosise of audit commitece fildancial experc

Sec. 806 Prencetion for employces of publicly traded companics who provide cevicense of fratud
- The Sccurities and Exchaigc Ac: amcnded in December 2003 clariftes prokibition on personal loans ou excelives and requires disc:osures of management corrponsation in annuxat. reports.

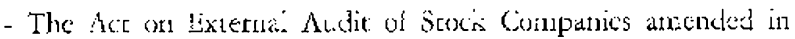

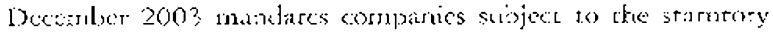
audic requircincrit to ma:xcaio an internal accounting control systcm. The $A c e$ also requires the statuony intemal cudien to arsess interal contol system and the statuco:y exremal anditor to accest ro, snd zepotr on, the assessrnent mace by the statutory internal auditur.

- T/k Securitis and lixchange Act anended in Decomixe 2003 requires that at lease nne member sf the audic commirtee of a compeny has expertisc in the accounting or finance asea arid that the audit comronitese of a sccurity company with stuck Jistex on the KSt: or KOSDAO be chaited by an independent meniber of the board of directors.

- The Act on Extemac Alidit of Srock Cumpsaies amenecd in Derember 2003 stipulares protection for id winsteblower who providec the $5 F^{\circ} \mathrm{C}$, extcrnal auditor, or statutory internal auditor with infumation about violations of established stenclards, auks: and regulations

- lihe Sccurity-related Class Accion Lawsuit Act cracted in December 2003 strengethenci investor procecrion by allowith minotivy shateholders collectively to bringr a lawsuir for accounting irregialaritics, untruthul disclosures in prospectus,

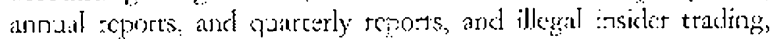
or stock price marnipilation, provided that the shareholders atc quáifited co sile a lawsuit. The now Ace also restricts the citumber of lavsuics that atey persen can fle or an atcorney can represent. to 3 lawsuits in 3 yeurs in o-der or minir ize frivolous barsuits. 
Iast but not least, English translation of the relevant regulations is recpusite, given bat the one thain purpose of liberalization is to induce more forcign investment. 'The Certified Public Accountant Law is significant for its liberalization of the Korean accouncancy market, and so it is quite surprising that there is no English translation of the law. Because language, obviously, is the most. important tool used in cstablishing cross-cultural understanding, it is clearly crucial to translate the relevant regulations into the international language of commerce - linglish - in improving clarity.

\section{Recommendations for the Private Sector: Individual Accounting Firms}

In order: to survive and thrive andid stiff global competition, cacl accountancy firm needs to have a creative vision. Mergers between small local accounting firms would be it good countcrneasure against accountancy market liberalization. However, such horizoncal integration or even vertical integration might not be enough to compete with the big. Western firms. Hence one recommendarion suggested here is to pursue conglomeration, especially with law firms. The areas of business of a law firm are broad. It not only practices litigation and arbitration but also deals in corporate and M\&A, capital markets, banking, projects, asset finance, real estate $\&$ construction, pensions \& incencives, financial markets, investment management and tax, ${ }^{5 / 1}$ $A$ this shows, the interests of a law firm are overlapped somewhat with those of an accounting firm. 'Therefore, if those two professional-scrvices industries - the legal and accountancy services industries -- work tugether, the inaprovement in produstivicy, effeciency and effertiveness will be more than two fold, and clicnes will be able to receive one-stop service. This one-stop service is already provided in lhailand by firms such as KPMG Tax \& legal, PricewaterhouseCoopers leyzal \& Tax Consultants I.td., and SCM Intcinational Law Office Ltd. 55

'The other recommendation is to explore new niche markets by operating a back office. An accounting fim works with lots and lots of paper, as well as electronic copies of documents. The firm needs to store those materials for both short-term and the long-term periods. It also needs to have a low-cost, efficient means of editing documenes, so that when a clicut has a document necrling wo be created or edited, the work can be runed around almost instandy, con if hundeds of pages long. Traditionally, there was a secretarial or word-processing pool of hundreds of secreratics working simultancously on one document. if necessary, in order to get the work done. Now, with word processing software, it can be accomplishcd wit! considerably fewer people. Nevertheless, document production needs to continue to grow, exponentially.

Such back offices are already in opcration in India, but not yet in Northeast Asia. For example, Unisof Datatech is a data entry and processing services provicter frotn India offering services to clients across the globe and within India. 
What they do is data encry and processing, data conversion, scanning, optical chatacter reading with editing and indexing services, form processing, wel research, bookkecping and accounting services, as woll ats financial services. 56 Since: Korea has at excellent IT infrastrucrure, this kind of back office operatior would work well in Korca and help Korea become the financial hut - or at last the financial information center - of Northeast Asia. A back office operation can even ioxducte document storage or archiving functions. Moreover, the launch of a global training center could also be cunsidered. 5 ?

If the upgrading of the domestic accountancy marker is delayed due to concerns about difficulties arising from such reforms, the growth potential of the Korean economy will be diminished. Exrernal liberalization slould be viewed as an opportunity to achieve internal reforms and economic yrowth, because the advanced avaijability, transparency and verifrability of financial information that would result from successful reforms would undoubedly artrace additional investmeat. The critical success lactors for achieving a world-class accounting systcm include [RRS compatibic accounting standards, rigorous implamentation by preparess of financial stacements, independen monitoring by external auditors, and an effective market response to deficiencies of players. 58 However, the stcps taken to liberalize the accountancy market should be prudential, bccuse once the Scheciule is revised or the market is libcralized, it is very hasd to so back.

\section{CONCLUSION}

Berause the accomnting indusay has been a fundamental infrastructure in the capitalist market cconomy, performing an efficient funcrion of distributing scarce economic resources through the appital market, 5 there have been ongoing international fforts, under the leadership of the WTO, to create a global market for accounting and auditing services. In response to the international demand, the Korcan govermment announced plans to liberalize its accounting market and other sectors from $200 \%$ and to fully open the rarket by the year 2011 . The liberalization of tine Koreati accountancy matket will be obligacory under the W'O pacts especially the CATS and "Revised Conditional Offer on the Schedule of Specific Commitments' for the Wra services acgotiations submitted by Korea on May 31, 2005. 'The anencment of rhe Certifed Public Accountant Law will follow sont to allow forcign accounting firms to open beanch offices in Korea.

The liberalizacion of the accouncancy masket means that non-nationals and even non-residents of a nation state would be able to offer accounting services under the same conditions as nationals, and foreign accounting firms might also be able to establish offices without involying locaily approved professional 
accountants. The effects of the liberalization can be both positive and negative dejending on the market and comomic situations inside and outside the country, as the SWOT analysis of the Korean accountancy market indicates. Ot the one hand, the liberalizarion of the accountancy market has the potential to restructure the market by facilitating $\mathrm{FDI}$, the transfer of advanced skills, the mobility of professional labor, the cross-border delivery of services, connectivity to global networks, and the merger of local practices to compete with forcign joint-venture firms. On the other hand, efforts to eliminate regulatory bayriers to rade in accounting and audiring services could have harmful side effects for the public interest, consumer protections, the relations of exchange between developed and developing countries, and the ability of goveriments to intervene in the conderet of bussiness.

Arnold Toynhee one wore that history moves according to challenge and response. Sometimes the challenge is too great and a society declines, breaks down or lies stagnant. Sometimes the challenge inspires a reaction that changes history. ${ }^{60}$ Whether the resule of liberalization is the former or the latter utterly depends on Korea and Koreans. The Korcan governmenc should undertake to minimize the prospective negative effects and maximize the prospective positive effects caused by accountancy markct libcralization. 'lo reap the full benefits of accountancy market liberalization, Korea should strengthen cooperation at the global level in the field of accourting services, creace grcater hamonization in accounting and auditing standards, improve the independence of CPAs, enlance the supervision and monitoring of accounting services, and reinforce corporate governance. Also, the innororrance of Finglish translation of the relevant regulations can never be ignored in this era of globalizarion. By overcoming all difficulties and challenges, someday Korea could at last escape the position of standard-taker and achieve the status of standard-maker.

The theme of this paper - the liberalization of the Korean accountancy market - is an ongoing issue. Subscqucintly, the simation changes day by day. Therefore, this is not the end of the study, but rather, constant and continuous attention to this issue is required. The possibilities for future studies are wide oper.

\section{REFERENCES}

Arnold, Patricia J. 2003. Internacional trade law and the political construction of professional service markers: A case study of corporate led glohalization. CMS 3( 7$)$.

Arnold, Patricia J. 2005. Disciplining domestic scgulation: The World irade Organization and the market for professional services. Anconting, Organizations and Society 30(4): $299-330$.

Canadian Bat Association. 2000. Submission to the Howe of Commons Subommittee 


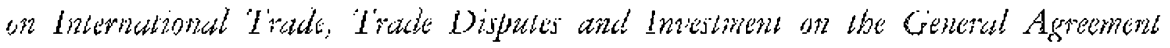
on Trade in Sontes and the Legal Profosson. The Acconntang Disciplintes as at Mridel for the Jegal Profesion, November.

Caramanis, C. 2002. The interplay between professional groups, the state and supranational agents: Pax Amcricana in the age of 'globalization'. Accounting, Organizations and Society $27(1-5)$ : 379-108.

Chane-Kune, Bernard and .Varno Mulder. 2000. The liberalization of inremational trade in services. Finanie, Inwestment and Groutb, Edition R.59.

Cooper, Christine. 2003. Discussants Comments of Gencining Acromting Beyond the Suate: The WTO and the Constrution of a "Wonld without Walls" for Accomating Sevices by Caroline Aggestam and Anre Lolt. The 7 ib Inlardiscibliwary perjoetives on Acounting Conference, July $13-16$.

Cooper, D. J., R. Greenwood and J. L. Brown. 1998. Globalization and Natonalism in a Multinational Accomntime Firm: The casc of openiry natkets in Fastern Furope. Accoualing, Orounizatons and Srider 23(5-6): 513-518.

Tioreign Press Spokesperson's Officc at MOFE of Korea. 2005. Acomming Market to Open in 2007 , December 7 .

GATT documents MTV.GNSWW 64 . Scheduling of milial Gomitmeni in Trade in Servitias.

Hockman, B. and Braga C. A. Primo. 997. Protection and trade in services: A survey. Open Economies Reviev 8(3): 285-308.

Iglauer, Philip Dorscy. 2006. Finaticial hut is Korea's luture. T'be Koroa T'imas, leluruary 20.

lndustry Canada (2001). GATS 2000 and Rules Goweming Domentio Regulations: GATS Artide Vi:A in context.

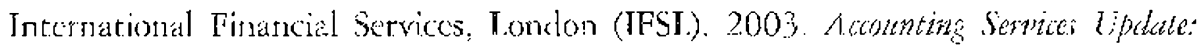
City Business Somer, October.

Kim, Il-Sup. 2000. Financial crisis and its impact on the accounting system in Korea. Korean Accountimz' Jounal 9(3): 7-109.

Kin, Ji-hyun. 2005. Deloitte CEO gives high marks so Kerear accounting industry. 'The Korea Hercald, Seprember 5.

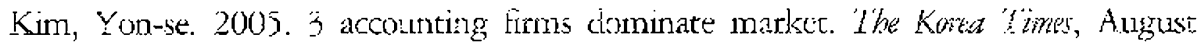
31.

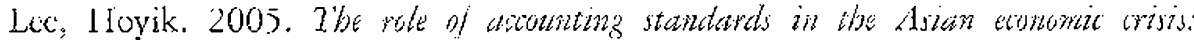
the Kowem expentine, HiRS Regional Policy forum, Syoney, Australia, Octobet. Lee, fang-yong. 2006. Regulatory reform and the roat of financial hub. The Kowet Hereld, May 9.

Ice, Tac Hec. 1999. Intwnational yoint Ventums in Komet. Center for International I.cgal Studies, October.

Opening Srarement by the Director of DiTC. 2005. Fxpert Meeing on Trade

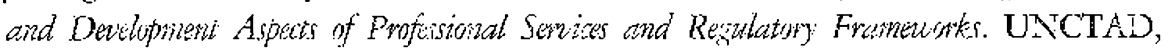
January 17. 
Pfiti, William. 2005. 200 $0^{\text {th }}$ contury wrecked Suropean, but not i..., zest for war. 760 Se-Gge llbo, January 25.

Primo, Braga C. A. 1993. The impact of internationalization of services and developing countries. Fizanie and Derielomment $30(1)$.

Rolerts, C. 2000. Promoring international trade in services: A priority for Furope. Europian Business Joumat 12(4): 199-206.

Seo, Jee-yeon. 2005. More foreign professionals to work in Korea from 2007. The Korea Thmes, May 23.

Sohn, Chan Hyun, Junsok Yang and Seung Beom Kim. 2002. Liberalization Measures in the Process of Korca's Corporatc Restructuring: Trade, Investhent and Capital. Account Makke Openings. Scoul: Korea lastinte for Intcrnational Fonomic Policy.

Trolliet, C. and J. Hcgarty. 2002. Regulatory retorm and the trade liberalization in servicas: The henefits and limitarions of strongthened CATS rules Accountancy services. OECD-Wonld Bank Semices Finert Mesting, OE(1)-Paris, March $4-5$.

Tuldw, Tereso Jr., Teresita Vadurata and Nimpha Aquino. 2001. An in-depth Srudy on the Accounting and Financial Industry in the Philippines, August 17.

United States Intemational Trade Comnossion. 1988. LS Schedules of Commimments

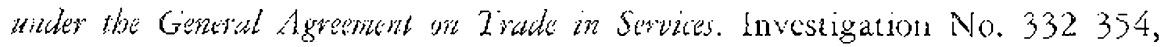
August.

White, I. J. 1999. Reducing tinc bastices to international trade in accounting services: Why it marters, and the road alead. The Comperence gin Service 2000: New Dinetichs in Semices Trode Liboralization. Washington, D.C., June 1-2, and The American Fotwphite enstitute. Washington, D.C., October 5.

World Bank and International Mionecary Fund. 2004. Repont sn the Ohservance of Siandards and Cotes (ROSC): Aconining und Auditing of the Repulitic of Korea, June 30 .

WTO. 1998. Council on 'Trade in Services, Decimon an Diriplines Rulating to

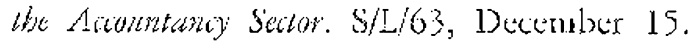

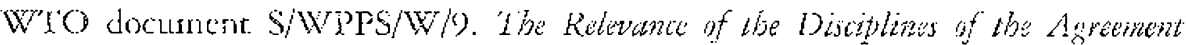

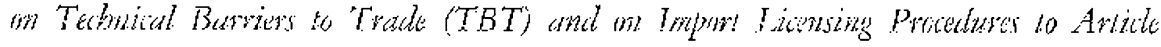
$1 / .4$ of the $G / 17 S$

Xian, P. R. 2005. Nemsondum of Underitanding (NoL) of the $5^{\text {t. }}$ Three Conutries' Acotinting Settens' Hecting between China, Japan and Korta, September 7 .

Yoon, Ja-young. 2006. IIS FTA to hit service industry hard. The Korea Times, April 21.

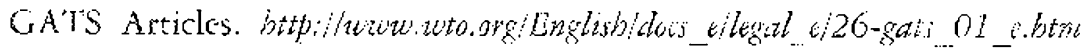

Korea Accounting institute/Korea Accounting Standard Board. btth:/hume. kabib.or.kr

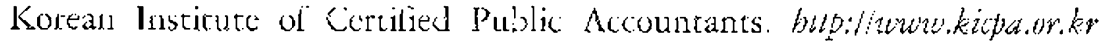




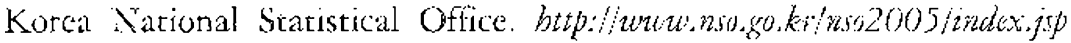

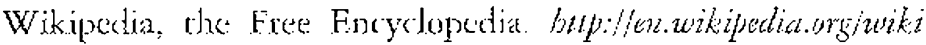 \\ WTO. blip:ilwwintong}

\section{ENDNOTES}

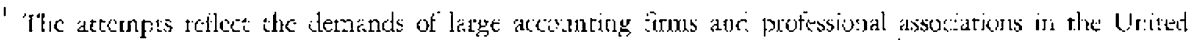

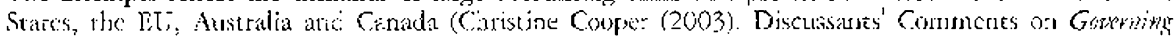

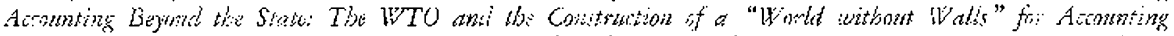

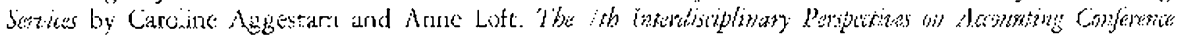
(Ji:y 13-16, 2003); p.i.).

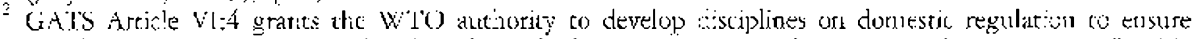

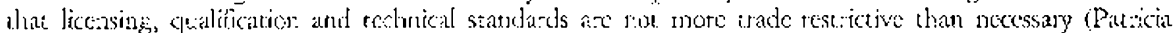

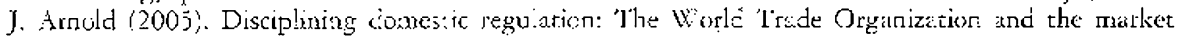

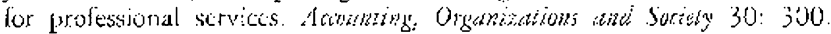

Under the finazized secerd offer to the W'TO for service nasker opening, 10 service sectors to brings

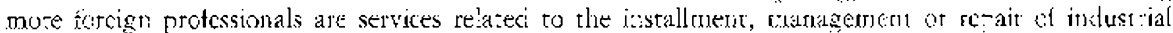

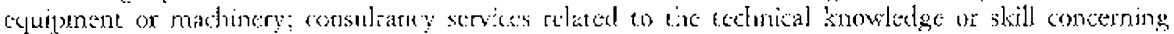

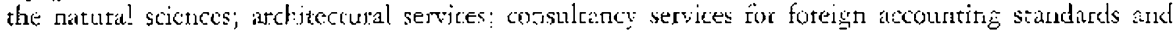

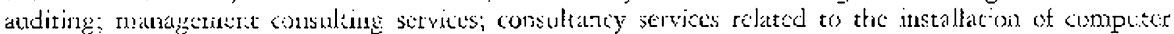
hardware, software research ix develo'ment-based implemenration sevicts; dita matigemest services; data systexu services and spccial:y c:ıgineering design services for auturabies (Seo Jee-yeor: Mure

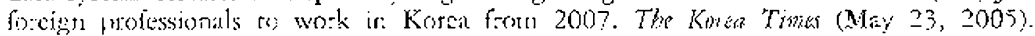

Forcign Press Spokespersor's Office at MOFI (2005). Airounting Marker to Open in 2(10) (Decenioer $7,20(15)$.

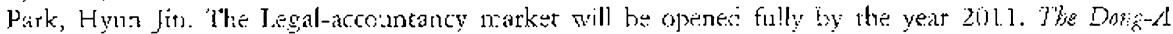
Ho (Hay 3, 2006).

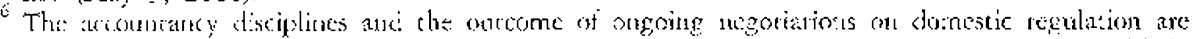
of enomous significance beth with and oussice the accouncing portession. Accountivg is lisely

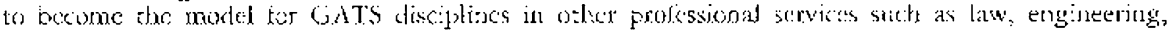
archite-nire, anc medicine. The WTO Working Party on Domestic Regulation (WPOR) his cer sickted

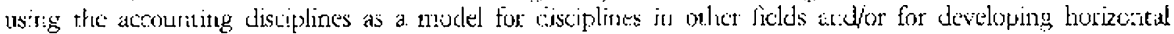
disciplines thike wosid apply es all prolessional services Arrold, 2005:30\$)

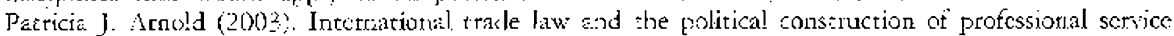

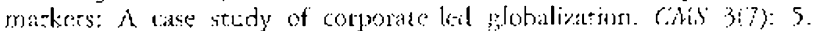

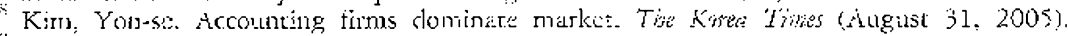

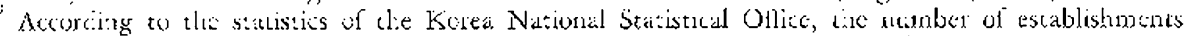

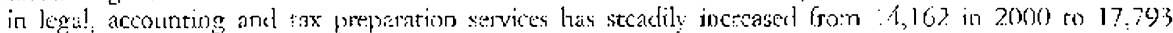
in 2004 , the number of werkers from 78,351 in 2000 to 100,922 in $200 \%$, and annuat saes from

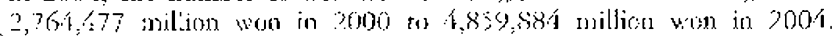

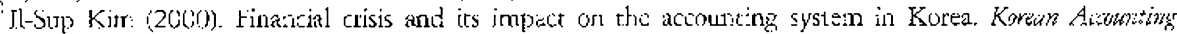
Jositial (o): $105-106$.

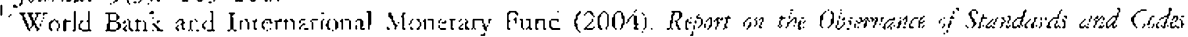

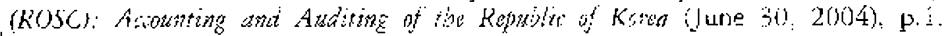

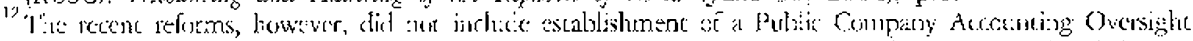
Boated (PCAOB3) to ovetsec alditors of public companies and issuance of auditing standarcs (Isida:2-5). "Wotk bank a:d Intersationat Honctary Lind (200\%), p.5.

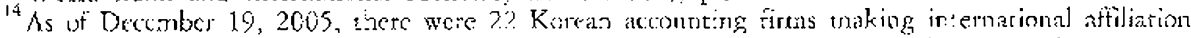
witi fo-cign accounting firms through membership concraces, such as Samil $P_{w C}$, Deloit:c Amjin

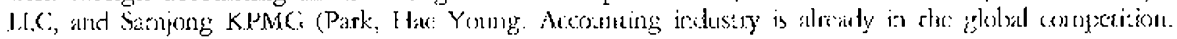

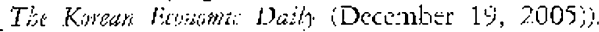

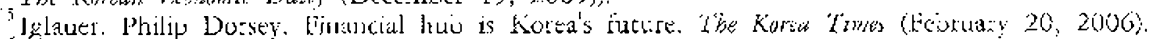

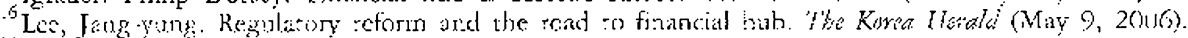

"lereso Tullio, jr.. Teresira Nadurata and Nimpha Aquiso (2601). Ar. In-depth Stusy or. tle Accounting

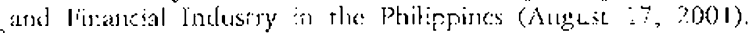

"Patcicia J. Amold (200); Incerracioral tradk law and the political consinction of professional servite natkeis: A case study of conporase-led globalization. Citis 3(T): 1.

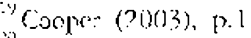

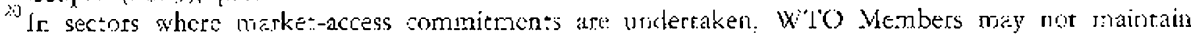




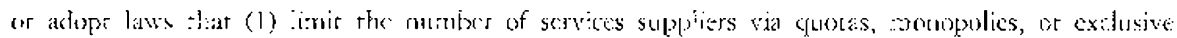
service sappliers, (2) limic the total value if service transactions, (3) limis: the totial au:mber of service

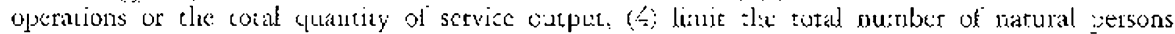
that may be employed in a partionlat sesvice sector, (5) restrict or requite specific types of legal entity or joint virture through which a service susplicr nay supply a sevice, or i6) ituit the participation

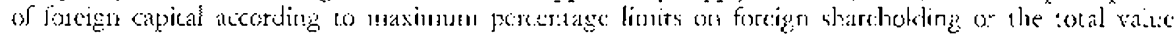
of individuai of aggregare foregn investment (GATS, Artice XVI). Cited in Arnold (2005), p.3ij5.

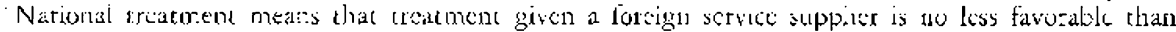
that accorded to domestic scrvicc supplices (Lited Stites Intemational Trate Commission (LSITC)

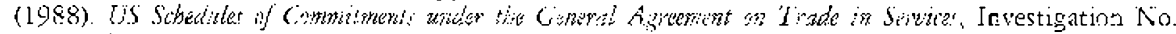

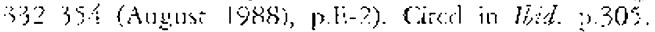

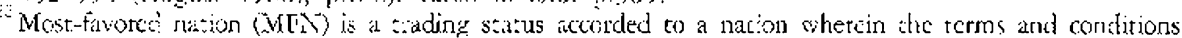

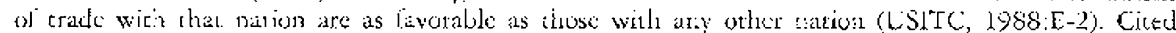
in libid, 10.305

-TNSSOKORRev.1. a revision n GAIS:SC

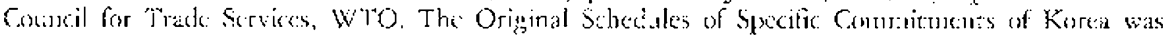
made o $A$ ipril 10 , 1995 .

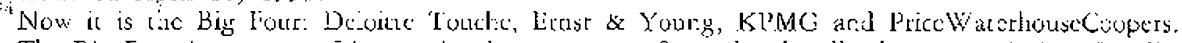

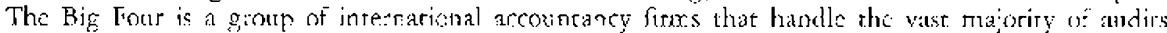

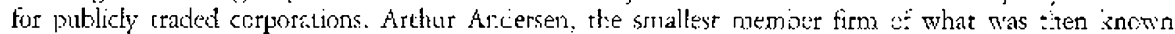

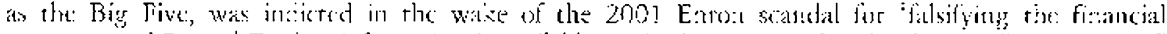

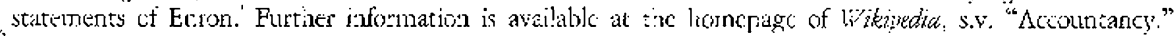

Kiris (2000): pp.92-104.

"Kirr, Yon-se (?o)

Under the prescar cegislation, Korean accounting firms can employ forcigr accountants ony after

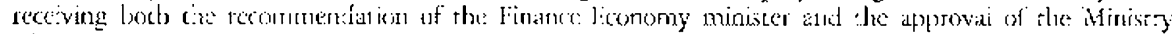
of jestice in the form ơ incervacional afialianon lor a period not excecsing one year. (Kim, Young

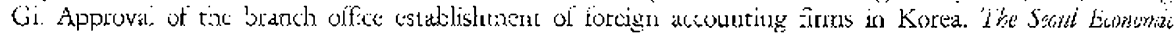
Dais): (sipr:] 2, ?(X)6).

loid.

Arnolid (20is), :3:3

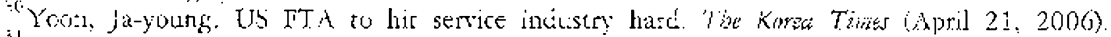

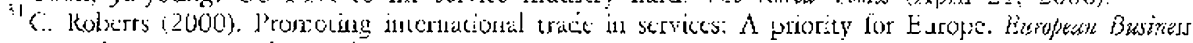
Jnornal: 1?, 190.?06. Cired :n Arnold (2005), p.32\%1

Annold (20)5), S.32í,

Ki:1 pooci, p.î?

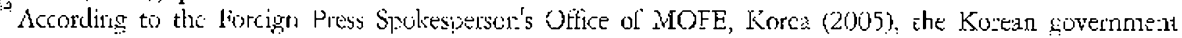
opens as acouriting marke: to muact trote forcign investors for its financial hib goal.

Amold (0(x)5), p.312. This part deals gene:ally in the prospective newative effects of the liberalization of rhe accosmancy matket. Therefore, it can be appeded ocyond Korea.

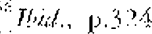

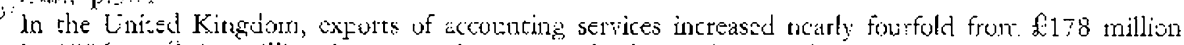

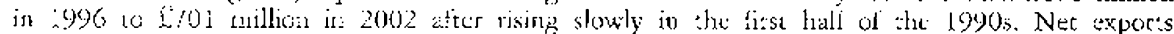

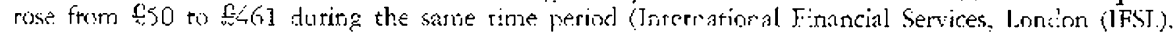

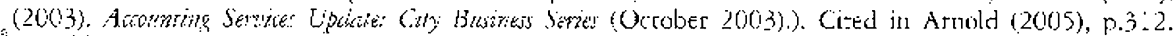
Arrold $(2005), 13] 2$.

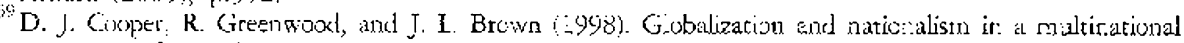

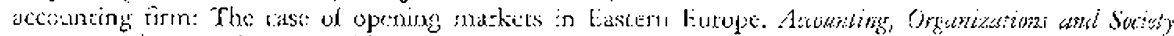
23: $513-548$. Ced in Arrold 2005$), 0.313$.

Ariold (2003), p.12

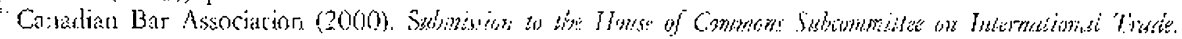

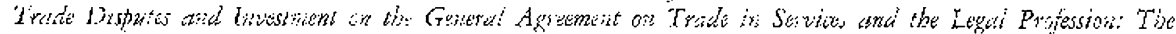

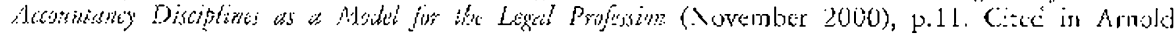
(20) 05$)$, p.313.

Prior to dercgulation in the 194)

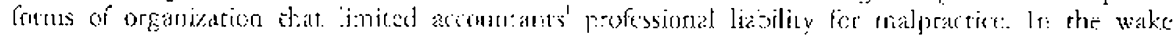
of the Fnrov scendal, the Ut:itcd States enacted the Sarbancs-Oxily Act of 2002 ro resserice auditing

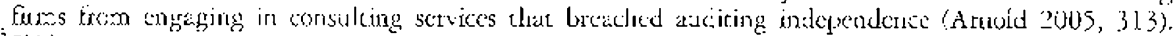

$\therefore=7 b i$.

$\therefore$ livit.

Nojil.

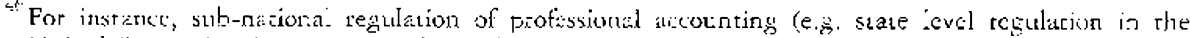

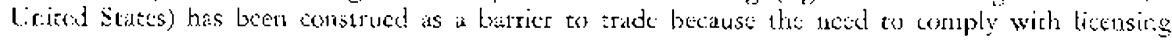




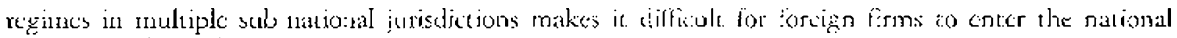
muarke: (lidid., 3]4),

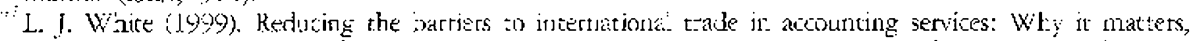

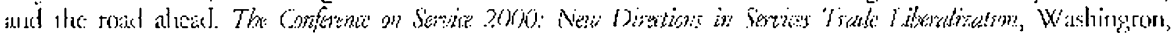

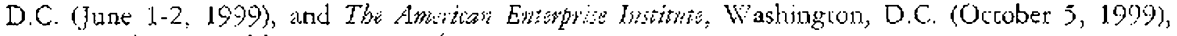
p.22. Cinesl in Amold (2005), p.jlít

Arnoli $(2005), \quad 3.314$

Armok: (200) 30300

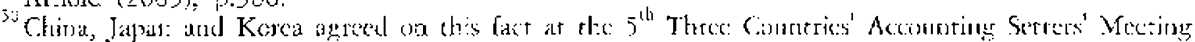

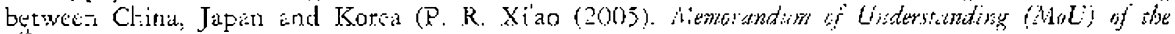

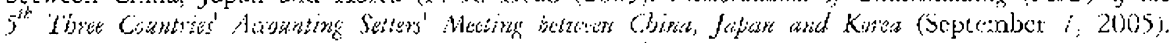

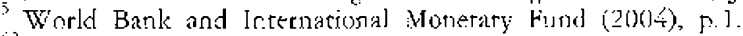

i2 biri.

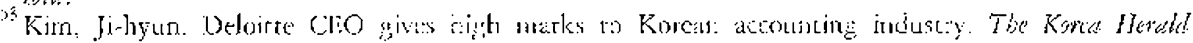
(Septenioe 5, 2005:.

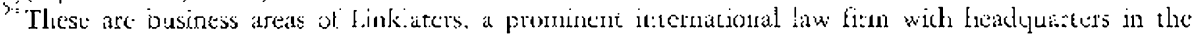

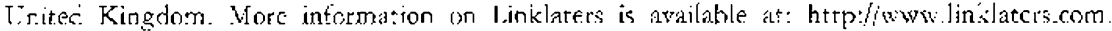

The SCW intcrational hatw Office is an international law and accolnoing firm, establisaed in 'Thailand

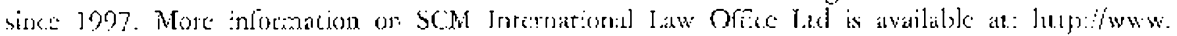
thailand daw cons.

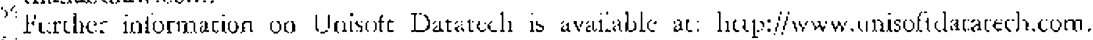

"This is the irka of Prot. Son (I Wichael Paik. "l"ze author woude like to thank kim for his kind help.

32 Rim $(2000)$, p. 106.

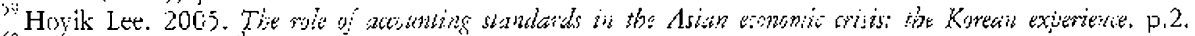

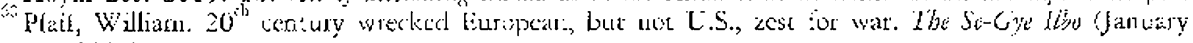
$25,2005)$ 